\title{
The impact of school principal's leadership styles on organizational learning: Mediating effect of organizational culture $^{1}$
}

\section{Okul müdürünün liderlik stilinin örgütsel öğrenmeye etkisi: Örgüt kültürünün arabuluculuk etkisi}

\author{
Mehmet Kızıloğlu²
}

\begin{abstract}
1 This article is an extended and improved version of the paper presented at the 6th International Management and Social Sciences Conference between 16 and 18 January 2021.
\end{abstract}

2 Dr, Pamukkale University, Denizli, Turkey, mkiziloglu@pau.edu.tr

ORCID: 0000-0002-6098-3980

\section{Submitted: $17 / 04 / 2021$}

Revised: 15/06/2021

Accepted: 2/07/2021

Online Published: 25/09/2021

Citation: Kızıloğlu, M., The impact of school principal's leadership styles on organizational learning: Mediating effect of organizational culture, bmij (2021) 9 (3): 822-834, doi:

https://doi.org/10.15295/bmij.v9i3.1814

\begin{abstract}
Educational institutions also focus on improving the quality to adapt to today's world's continuous and rapidly changing conditions. In improving the quality of educational institutions, the leadership styles of school principals and the organizational learning that can be applied in school are significant. The leadership styles of school principals and organizational learning are also influenced by the culture that has been settled in the school. In this context, this study was conducted to investigate the impact of leadership styles on organizational learning in high schools. The main focus of this research study is on analyzing the critical role of different leadership styles on organizational learning through the use of a quantitative research approach. The primary data in the current study has been collected from 310 high school teachers working in educational institutions of Turkey. The study found that leadership styles have a significant impact on organizational learning. In addition, transformational and transactional leadership styles positively affect organizational learning, and laissez-faire leadership style hurts organizational learning. However, organizational culture has also been found to mediate the relationship between leadership styles and organizational learning significantly.
\end{abstract}

Keywords: Transformational Leadership Style, Transactional Leadership Style, Laissez-Faire Leadership Style, Organizational Learning, Organizational Culture

Jel Codes: M10, M12, M14

Öz

Günümüz dünyasının sürekli ve hızlı değişen şartlarına uyum sağlayabilmek için eğitim kurumları da kalitesini arttırmaya odaklanmıştır. Eğitim kurumlarının kalitesinin arttırılması sürecinde okul yöneticilerin liderlik tarzları ve bununla birlikte okulda uygulanabilecek örgütsel öğrenme süreçleri hayati bir öneme sahiptir. Gerek okul yöneticilerinin liderlik tarzları gerekse de örgütsel öğrenme süreci okulda yerleşmiş olan kültürden de etkilenmektedir. Bu bağlamda gerçekleştirilen bu çalışma, lise düzeyindeki okullarda liderlik tarzlarının örgütsel öğrenme üzerindeki etkisini araştırmak amacıyla yapılmaktadır. Çalışmada liderlik tarzı ve örgütsel öğrenme arasındaki ilişki üzerinde örgüt kültürünün aracı rolü de analiz edilmiştir. Çalışma, liderlik stillerinin örgütsel öğrenme üzerinde önemli bir etkisi olduğunu ortaya koymuştur. Ayrıca dönüşümcü liderlik tarzı ile işlemsel liderlik tarzının örgütsel öğrenme üzerinde olumlu etkisi olduğu ve tam serbesti tanıyan liderlik tarzının örgütsel öğrenme üzerinde olumsuz bir etkisi olduğu saptanmıştır. Bununla birlikte, örgüt kültürünün liderlik tarzları ile örgütsel öğrenme arasındaki ilişkiyi de önemli ölçüde aracılık ettiği bulunmuştur.

Anahtar Kelimeler: Dönüşümsel Liderlik, İşlemsel Liderlik, Serbesiyetçi Liderlik, Örgütsel Öğrenme, Örgüt Kültürü

JEL Kodlari: M10, M12, M14 


\section{Introduction}

Due to the increased pressure of producing remarkable and competent students and competent future employees, different institutions have started focusing on improving the quality of education. The economic development of a country depends highly on its students' education and learning ability. Due to this reason, there is a need of focusing on improving the quality and level of education in countries (Khan \& Khan, 2019). Moreover, the government of Turkey has also introduced various measures for improving the quality of learning in institutions (Arar \& Nasra, 2019). As a result of increased competition among countries, the role of principals in schools and colleges has become complex because the success of the whole educational institution depends on the approaches and strategies followed by school principals. Due to this reason, different scholars have started exploring effective leadership styles, which school principals must adopt in order to improve organizational learning. Such organizations focus on adopting learning in a team and creating a vision (Serinkan, Kiziloglu, Akcit, \& Enli, 2014). The principals are a critical element in an institution that can help make a significant difference to what students gain. The ultimate performance of students depends on the approaches and strategies followed by school principals (Syakur, Susilo, Wike \& Ahmadi, 2020). As per research findings (e.g. Torlak \& Kuzey, 2019), it has been found that the educational institution's success depends on the effective educational leader, so this research focuses on leadership. Tang and Yeh (2015) carried out a research study and found that organizational culture positively affects organizational innovation, as it is related to organizational learning. Management's responsibility is to give considerable importance to developing a positive organizational culture to encourage innovation within the firm. In addition to this, Xie (2019) also found that transformational leadership is the most effective leadership style, which helps in encouraging better organizational learning. With the help of following transformational leadership style, managers in an organization become capable of making the firm a learning organization.

The findings of Kalkan, Altınay Aksal, Altınay Gazi, Atasoy and Dağlı (2020) were quite interesting hence used as basis of current research study. The transformational leadership (TFL) style is one of the most effective leadership styles that can help enhance the corporate image. School principals in some districts of Konya, Turkey, used to follow the transformational leadership style (Kalkan et al., 2020). Even though few studies have examined the importance of leadership style for educational institutions (Abbas et al., 2012; Onorato, 2013; Sadeghi \& Pihie, 2013), however, none of the prior research studies investigated the impact of different leadership styles on organizational learning, especially in the context of higher schools of Turkey. Moreover, no prior studies have investigated the relationship between leadership styles and organizational learning (OL), along with the mediating effect of organizational culture. So, this research study has added value to the literature by studying the influence of leadership styles on organizational learning and the mediating role of organizational culture (OC) in the context of higher schools of Turkey.

\section{Theoretical background}

\section{Theory of leadership}

According to Bass's leadership theory, three unique leadership styles have been proposed: transformational, transactional, and laissez-faire. This theory has been used in this research study to identify three key leadership styles to find their impact on organizational learning. While following the TFL style, leaders play guides and mentors and focus on inspiring, nurturing, and giving identity to subordinates to become higher performers (Tang, 2019). The focus of transactional leadership (TSL) style is on the use of rewards and punishments to manage the work of team members. In the end, while following the laissez-faire leadership (LFL) style, an individual focuses on imposing rules without providing support and guidance, due to which subordinates are provided with leeway in deciding essential standards and approaches. TFL style is linked with the positive behaviour of team members. However, the link of the laissez-faire leadership style is with negative behavioural consequences. The laissez-faire leadership style, known as the ineffective style, is the opposite of the transformational leadership style (Breevaart \& Zacher, 2019).

\section{Transformational leadership and organizational learning}

In today's competitive world, the transformational leadership style is a significant and preferred type of leadership (Devece, Palacios \& Ribeiro-Navarrete, 2019). Khan and Khan (2019) found that a culture of learning is also an essential key to being competitive, and this is achieved with the help of transformational leadership. Transformational leadership develops intelligence in employees, which result in enhancing creativity as well as learning. Organizational learning gets influenced with the help 
of socialization, which is considered a critical element of transformational leadership. It is referred to as visionary, and it is one of the most emotional factors for students, which results in enhancing the overall performance of students in schools (Imran, Ilyas \& Aslam, 2016). According to Bouwmans, Runhaar, Wesselink and Mulder (2017), TL helps increase the viability of unit performance. Its focus is on the use of motivational tools which can ultimately bring orientation towards effective learning in companies.

Consequently, the capability of prospering organizational learning in companies gets enhanced. Generally, it is claimed that there is an increased consistency between transformational leadership style and organizational learning in innovative economies. However, very few studies have examined the importance of the transformational leadership style for improving learning in an organization (Nguyen \& Luu, 2019; Andriani et al., 2018). However, researchers did not focus specifically on the Turkish educational sector.

\section{$\mathrm{H}_{1}$ : There is a significant impact of transformational leadership style on organizational learning.}

\section{Transactional leadership and organizational learning}

In addition to the transformational leadership style, another leadership style is the transactional leadership style. The transactional leadership style focuses on bringing incremental improvement in followers with the help of a transaction that can include reward or punishment. Transactional leaders are known as critical contributors to creating learning opportunities and enhancing organizational learning. The critical focus of transactional leadership behaviour is constructing the foundation to specify the expectations, negotiate contracts, clarify responsibilities, and offer rewards and recognition to achieve the set goals and expected performance between followers and leaders (Zagoršek, Dimovski, \& Škerlavaj, 2009). Thus, the transactional leadership style satisfies the need of followers through rewards and recognition after achieving set goals and objectives.

With the help of the transactional leadership style, the critical focus of leaders is on fostering the commitment of followers towards new ideation through gaining tangible recognition or rewards, which ultimately results in generating new ideas. Hence, the value communication is done directly to followers regarding leaders' attachment in the program participation. The transactional leadership style is helpful for followers for improving their ability to learn, and it helps explain the target to achieve objectives. Transactional leadership helps in making followers able to realize the significance of self-efficacy when key targets are achieved. Moreover, the transactional leadership style seems appropriate for followers' motivation to contribute and participate in ideation programs of the firm. Transactional leadership behaviour aims to drive excellence and efficiency to encourage followers to organizational learning programs (Berson, Nemanich, Waldman, Galvin, \& Keller, 2006).

\section{$\mathrm{H}_{2}$ : There is a significant impact of transactional leadership style on organizational learning.}

\section{Laissez-faire leadership and organizational learning}

Laissez-faire leadership is another style of leadership that is referred to as the absence of leadership. The laissez-faire leadership style is generally known as ineffective leadership style, which is driven by a failure to take accountability to manage, including omission of reward or punishment. Moreover, the laissez-faire leadership style is a destructive style of leadership, which ultimately results in increased stress levels within the firm. This leadership style generally results from negligence or ignorance; however, it can also result from respect from a leader. Hence, provided the possibility that a leader's laissez-faire leadership style is a strategic choice and subordinates can positively perceive this. Therefore, there is a need to approach the laissez-faire leadership style more balanced to steer away from a conventional point of view and through subsequent links with adverse outcomes (Breevaart \& Zacher, 2019). Glambek, Skogstad and Einarsen (2018) found that a laissez-faire leadership style can help achieve key objectives and goals. However, it cannot play a role in improving organizational learning within the firm.

The satisfied needs of employees can result in prompting self-absorption. The reinforcement theory is used to explain the negative influences of engagement of a leader. The reinforcement theory supports the need to give employees feedback on the performance of subordinates concerning cognitive and social rewards. However, this type of reinforcement can also result in low levels of reasoning and conduct since employees do not get engaged in cognitive processes themselves. However, they are forced to do so (Yang, 2015). Hence, different scholars have analyzed the influence of the laissez-faire leadership style, but none of the studies focused on investigating its impact on organizational learning in Turkish high schools. So, the focus of the current research study is on investigating the influence of the laissez-faire leadership style on organizational learning in Turkish high schools. 
$\mathrm{H}_{3}$ : There is a significant impact of the Laissez-faire leadership style on organizational learning.

\section{Mediating effect of organizational culture}

Companies are formed with people who are raised in various social-cultural regions that have various values and rules. In addition to this, the culture that describes a community's living style can get differentiated between companies and societies. Organizational culture is an important idea that involves the link of activities and aims of the company with social norms and the analysis of attitudes and movements of individuals within the people. A strong culture of the company is adopted through employees and management with shared values and beliefs is more significant in developing the structure that has acquired sustainable growth (Xie, 2019). The structure in the school is usually emerged based on the organisation's culture, and it acquired a good place in the education field. The idea of school culture, mainly after the 1980s, has been used to define the comprehensive character of the idea of company culture in educational firms (Mannion \& Davies, 2018). It works to fulfil the expectations of individuals and to make a positive culture within the school. One of the critical challenges identified in the school's culture is the weak and robust culture of the school. When leaders follow a transformational leadership style in schools while having a supportive culture, this helps enhance motivation to teach and learn. Over this, honest and sincere links among school members and the action sense together become more significant. Administrators in this environment have a clear sense of purpose and duty. They make positive links within organizational members and transform school as some sustainable structure into a learning company with partners' participation (Curry et al., 2018). The school culture is the most significant factor that identifies the school's perception and the behaviour patterns of different partners, particularly students and teachers. Over here, the shared leadership style comes into action, and this study analyses the role of leaders in organizational culture. In addition to this, Rijal (2010) conducted a research study for understanding the relationship between leadership style and organizational culture. They found that different leadership styles are linked with the development of different types of organizational culture. It is not possible to gain positive outcomes in an organization by following a transformational leadership style. However, there is always a need to develop motivating culture and empowered culture in an organization.

Within the literature, research has identified that leadership behaviour identified through school administrators empowers employees' organizational commitment and enhances the work-life quality through a supportive organizational culture. It also increases satisfaction at the job, organizational health, and leadership styles (Erthal \& Marques, 2018). In addition to this, the company's culture and working style mediate the link between job satisfaction and leadership style. There is proof that leadership shown through the school administrator plays a significant role in growing and shaping the organizational culture. In contrast to this, laissez-faire leadership tends to influence teachers' trust in school negatively. There is a negative and significant direct link between organizational cynicism and transformative leadership.

$\boldsymbol{H}_{4}$ : OC significantly mediates the relationship between TFL and OL.

$\mathrm{H}_{5}$ : OC significantly mediates the relationship between TSL and OL.

$H_{6}$ : OC significantly mediates the relationship between LF and OL.

\section{Methods}

\section{Research approach}

In order to analyze the impact of leadership styles on organizational learning in educational institutions of Turkey, a quantitative research approach has been used. As per the quantitative research method, the researcher has focused on using facts and figures. According to this approach, the key focus is placed on the testing of theory. This method proved to help generate reliable and valid research outcomes (Kothari, 2004), ensuring less bias owing to its high objectivity and accuracy (Goddard \& Melville, 2004).

\section{Population and sampling}

The research is based on the population of educational institutions of Denizli/Turkey. The whole population of the study is all high school teachers working in educational institutions of Denizli/Turkey, which is 3750 high school teachers. A sample of 310 respondents was selected based on the purposive sampling technique. The selected purposive sampling was a type of non-probability sampling, according to which researchers relied on judgments while selecting members from the selected population. As the researcher lives in Denizli/Turkey, the data were collected from those teachers working in higher schools of Denizli/Turkey, who were readily and easily available. As the study was mainly focused on exploring the impact of leadership styles on organizational learning in the 
case of educational institutions of Turkey, it was essential to select teachers working in those institutions to get their point of view. After distributing questionnaires, the researcher collected 310 out of 400 filled questionnaires. The researcher used this sampling strategy, as it helped in conducting the research survey in a lesser period (Kumar, 2018).

Table 1. Demographic Analysis

\begin{tabular}{cccc}
\hline & & Frequency & Percent \\
\hline Gender & Male & 220 & 71 \\
& Female & 90 & 29 \\
\hline Age & $20-29$ & 93 & 30 \\
& $30-39$ & 60 & 19 \\
& $40-49$ & 93 & 30 \\
& $50-59$ & 64 & 21 \\
\hline
\end{tabular}

The primary data in the current research study has been collected from 310 teachers working in higher schools in Turkey. Among 310 respondents, there were 220 males and 90 females (as shown in Table 1). It means there was more percentage of male teachers as compared to female teachers. Their age was also analyzed, and it was found that $30 \%$ of respondents belonged to $20-29$ years of age, $19 \%$ belonged to the age group of 30-39 years. In addition to this, $21 \%$ of respondents belonged to $50-59$ years. Therefore, most people who participated in the study belonged to the age group of 20-29 and 40-49.

\section{Research instrument}

The questionnaire consisted of items related to leadership styles and their impact on organizational learning. The items related to leadership styles were taken from the research study of Muthiani (2019), organizational culture items from O'Reilly III et al. (1991) and organizational learning items from Mullford (2005). In order to ensure the reliability of the questionnaire, the pilot study was conducted. In the pilot study, the researcher collected data from 85 respondents and then value of Cronbach's alpha; TFL (0.97), TSL (0.82), LFL (0.82), OC (0.75) and OL (0.70). The questionnaires were distributed to teachers of higher educational institutions to get their point of view about leadership styles followed by principals and their impact on organizational learning. The items added to the questionnaire were designed based on a five-point Likert scale. As per the five-point Likert scale, $1=$ Strongly Disagree, $2=$ Disagree, $3=$ Neutral, $4=$ Agree, and $5=$ Strongly Agree.

\section{Data analysis}

After collecting data through questionnaires, it was analyzed with the help of the descriptive analysis technique. Besides this, the researcher also checked the normality of data through values of skewness and kurtosis. Moreover, regression analysis and correlation analysis were used to test the influence of critical, independent variables on the dependent variables. Moreover, the reliability analysis of the questionnaire used in the study was also checked using the value of Cronbach's alpha.

\section{Findings and results}

\section{Descriptive statistics}

The findings of mean and standard deviation for all variables have been included in Table 2. From table 2 , it can be seen that the perception of teachers about transformational leadership is at an intense level $(\mathrm{M}=3.5097, \mathrm{SD}=0.58940)$. On the other hand, the value of standard deviation for transformational leadership is relatively low, which there is not much dispersion in the data, and almost all values are closer to the mean value. Moreover, the perception of teachers about laissez-faire leadership style is at the medium level $(\mathrm{M}=2.3016, \mathrm{SD}=0.64374)$, which means the value of standard deviation is not too high, so there is not much dispersion in data collection related to laissez-faire leadership style, and the perception about transactional leadership style is at low level $(\mathrm{M}=2.2538, \mathrm{SD}=0.43751)$. It means, as compared to other variables, the value of standard deviation is lowest for transactional leadership style. Hence, all values are closer to the mean value. Along with this, the perception regarding mediating effect of organizational culture is relatively high $(\mathrm{M}=3.4505, \mathrm{SD}=0.64881)$, which means, as per most respondents, organizational culture is something that significantly mediates the relationship between leadership styles and organizational learning and the value of standard deviation is low, so there is no dispersion in data. The ' $\mathrm{N}$ ' value depicts the total number of responses, which is 310 for all variables. 
Table 2. Descriptive Statistics and Correlation Statistics

\begin{tabular}{|c|c|c|c|c|c|c|}
\hline & \multicolumn{2}{|l|}{ Mean } & Std. Deviation & $\mathbf{N}$ & & \\
\hline $\mathrm{OC}$ & \multicolumn{2}{|l|}{3.4505} & .64881 & 310 & & \\
\hline TSL & \multicolumn{2}{|l|}{2.2538} & .43751 & 310 & & \\
\hline LFL & \multicolumn{2}{|l|}{2.3016} & .64374 & 310 & & \\
\hline OL & \multicolumn{2}{|l|}{3.1376} & .56671 & 310 & & \\
\hline TFL & \multicolumn{2}{|l|}{3.5097} & .58940 & 310 & & \\
\hline & & 1 & 2 & 3 & 4 & 5 \\
\hline \multirow{2}{*}{\multicolumn{2}{|c|}{ Organizational Culture }} & 1 & & & & \\
\hline & & 310 & & & & \\
\hline \multirow{3}{*}{\multicolumn{2}{|c|}{$\begin{array}{l}\text { Transactional } \\
\text { Leadership }\end{array}$}} & -.054 & 1 & & & \\
\hline & & .339 & & & & \\
\hline & & 310 & 310 & & & \\
\hline \multirow{3}{*}{\multicolumn{2}{|c|}{ Laissez-faire leadership }} & -.005 & $.126^{*}$ & 1 & & \\
\hline & & .932 & .027 & & & \\
\hline & & 310 & 310 & 310 & & \\
\hline \multirow{3}{*}{\multicolumn{2}{|c|}{$\begin{array}{l}\text { Organizational } \\
\text { Learning }\end{array}$}} & $.183^{* *}$ & .097 & $-.116^{*}$ & 1 & \\
\hline & & .001 & .090 & .042 & & \\
\hline & & 310 & 310 & 310 & 310 & \\
\hline \multirow{3}{*}{\multicolumn{2}{|c|}{$\begin{array}{l}\text { Transformational } \\
\text { Leadership }\end{array}$}} & .109 & .041 & -.072 & $.142^{*}$ & 1 \\
\hline & & .055 & .476 & .208 & .012 & \\
\hline & & 310 & 310 & 310 & 310 & 310 \\
\hline
\end{tabular}

Table 2 include correlations statistics for each variable. For example, the value of Pearson Correlation for the relationship between Transformational Leadership and Organizational Learning is 0.142, and the significance value is 0.012 . It means there is a weak significant and positive correlation between TFL and OL.

The value of Pearson Correlation for the relationship between Transactional Leadership and Organizational Learning is 0.097 , and the significance value is 0.090 . As the significance value is 0.09 , which means the relationship is significant at a $90 \%$ confidence interval, the relationship is insignificant. Therefore, based on the value of Pearson correlation, it is found that there is a weak significant and positive correlation between TSL and OL.

In addition to this, the value of Pearson Correlation for the relationship between Laissez-faire leadership style and Organizational Learning is -.116, and the significance value is 0.042 . As the value of significance is less than 0.05 , the relationship between variables is significant. However, as Pearson Correlation's value is negative, the Laissez-faire leadership style hurts Organizational Learning. Therefore, the Pearson correlation value depicts a weak and negatively significant correlation between LFL and OL.

The correlation statistics also includes an analysis of the relationship between Organizational Culture and Organizational Learning. The value of Pearson Correlation for the relationship between Organizational Culture and Organizational Learning is 0.183 , with a 0.001 significance value. It means there is a weak and positively significant relationship between OC and OL.

\section{Normality assumption}

Table 3. Normality Statistics

\begin{tabular}{llllll}
\hline & $\mathbf{N}$ & Skewness & & Kurtosis & \\
& Statistic & Statistic & Std. Error & Statistic & Std. Error \\
\hline OC & 310 & .008 & .138 & -.500 & .276 \\
T & 310 & -.139 & .138 & -.136 & .276 \\
LF & 310 & .241 & .138 & .353 & .276 \\
OL & 310 & -.627 & .138 & .512 & .276 \\
TL & 310 & -.732 & .138 & .013 & .276 \\
Valid N (listwise) & 310 & & & & \\
\hline
\end{tabular}

From the skewness values, it can be seen that all values are less than -1 , so it means the distribution is left-skewed. However, the kurtosis values are low, which means there are no outliers in the data set. 
Moreover, all values are within the range of +3 and -3 (Limpert \& Stahel, 2011), so it means the data is normally distributed, so this assumption for regression is also met.

\section{Multicollinearity test}

As the assumption of normality for regression analysis has been met, it is now essential to test whether there is a similarity between independent variables. In order to check this, a multicollinearity test has been performed. In order to have a good regression model, it is essential to have no multicollinearity in the data set. Therefore, when values of VIF are between 1 to 10 , it means there is no multicollinearity.

Table 4. Multicollinearity Statistics

\begin{tabular}{llll}
\hline Model & & $\begin{array}{l}\text { Collinearity Statistics } \\
\text { Tolerance }\end{array}$ & VIF \\
\hline 1 & (Constant) & & \\
& T & .983 & 1.017 \\
& LF & .982 & 1.019 \\
& TL & .996 & 1.004 \\
(Constant) & & \\
& T & .980 & 1.020 \\
& LF & .982 & 1.019 \\
& TL & .994 & 1.006 \\
& OC & .996 & 1.004 \\
\hline
\end{tabular}

As the values of VIF for all variables are between 1 and 10, it means there is no multicollinearity. Hence, this assumption is also met (Daoud, 2017).

\section{Durbin-Watson test}

Durbin-Watson test is used to test the auto-correlation in residuals. According to the rule of thumb, it is important to have values between 1.5 to 2.5 to meet this assumption for regression statistics (Freund \& Wilson, 2006). For current data, the value of Durbin-Watson is 1.993, which means it is more significant than 1.5 and less than 2.5 , so it means this assumption is met.

Table 5. Durbin-Watson Values

\begin{tabular}{llllll}
\hline Model & $\mathbf{R}$ & R Square & $\begin{array}{l}\text { Adjusted } \\
\text { Square }\end{array}$ & $\begin{array}{l}\text { R Std. Error of the } \\
\text { Estimate }\end{array}$ & Durbin-Watson \\
\hline 1 & $.176 \mathrm{a}$ & .031 & .021 & .56060 & \\
2 & $.256 \mathrm{~b}$ & .066 & .053 & .55140 & 1.993 \\
\hline & $\begin{array}{l}\text { a. Predictors: (Constant), TL, T, LF } \\
\text { b. Predictors: (Constant), TL, T, LF, OC } \\
\text { c. Dependent Variable: OL }\end{array}$ & & & \\
\end{tabular}

\section{Regression analysis}

In this study, regression analysis was used for determining whether dependent variables are predicted through independent variables about the third sub-dimension of the study as the study included mediator, which is referred to as the third variable, which allows a provided argument for influencing a specific dependent variable, so mediation analysis has also been done in this study. It is essential to have a significant relationship between mediating variables and predictor variables. Therefore, it is essential to have a significant relationship between these variables when regression analysis is performed. When entry mediating variable and predictor variable is done synchronically, the relationship can get non-significant, or a reduction in the introductory level of significance has resulted. In this research study, three leadership styles (TFL, TSL and LFL styles) were studied as independent variables and organizational learning was studied as a dependent variable. Moreover, the analysis has been done on whether or not organizational culture (school culture) plays a mediating role in the relationship between leadership styles and organizational learning. 


\section{Multiple linear regression}

Table 6. Model Summary

\begin{tabular}{llllll}
\hline Model & R & R Square & Adjusted R Square & $\begin{array}{l}\text { Std. } \\
\text { Estimate }\end{array}$ & Error of the \\
\hline 1 & $.206 a$ & .042 & .033 & .55726 \\
\hline
\end{tabular}

a. Predictors: (Constant), LFL, TFL, TSL

Table 6 shows that the value of $\mathrm{R}$ square is 0.042 , which means $4.2 \%$ of the data fit the regression model. Thus, even though $\mathrm{R}$ square's value is positive, its value is not that high, so it means the data is not a better fit into the model.

Table 7. Anova

\begin{tabular}{lllllll}
\hline Model & & Sum of Squares & Df & Mean Square & F & Sig. \\
\hline 1 & Regression & 4.215 & 3 & 1.405 & 4.525 & $.004 \mathrm{~b}$ \\
& Residual & 95.023 & 306 & .311 & & \\
& Total & 99.239 & 309 & & & \\
\hline
\end{tabular}

a. Dependent Variable: OL

b. Predictors: (Constant), LFL, TSL, TFL

The F-statistics has been used to analyze whether the dependent variable is predicted through independent variables. As the value of $\mathrm{F}$ is greater than 1 , the relationship between independent and dependent variables is significant.

Table 8: Coefficients

\begin{tabular}{|c|c|c|c|c|c|c|}
\hline \multirow{2}{*}{\multicolumn{2}{|c|}{ Model }} & \multicolumn{2}{|c|}{ Unstandardized Coefficients } & \multirow{2}{*}{$\begin{array}{l}\text { Standardized } \\
\text { Coefficients } \\
\text { Beta }\end{array}$} & \multirow[b]{2}{*}{$\mathbf{t}$} & \multirow[b]{2}{*}{ Sig. } \\
\hline & & B & Std. Error & & & \\
\hline \multirow[t]{4}{*}{1} & (Constant) & 2.634 & .269 & & 9.777 & .000 \\
\hline & TFL & .124 & .054 & .129 & 2.301 & .022 \\
\hline & TSL & .138 & .073 & .106 & 1.883 & .061 \\
\hline & LFL & -.105 & .050 & -.120 & -2.117 & .035 \\
\hline
\end{tabular}

a. Dependent Variable: OL

Table 8 illustrates the value of the beta coefficient of the regression model for the relationship between transformational leadership style and organizational learning. As this model regresses organizational learning on transformational leadership, table 8 indicates the beta coefficient as 0.124 . The beta coefficient depicts the slope of the relationship, i.e. the change in the dependent variable by a unit change in the independent variable.

In a current research study, the beta coefficient implies that a $1 \%$ change in the transformation leadership will bring about a $12.9 \%$ change in organizational learning. In addition, the beta value is positive. Therefore, it implies a positive relationship between organizational learning and transformational leadership, i.e. an increase in transformational leadership is expected to bring a $12.9 \%$ increase in organizational learning. Therefore, as the beta coefficient is significant, the null hypothesis is rejected, and it is concluded that there is a significant impact of the transformational leadership style of principals on organizational learning in the case of higher schools of Turkish.

Model for organizational learning and transactional leadership style indicates that value of significance is 0.061 and value of beta is less than 2 , which means the null hypothesis is accepted and alternative hypothesis $(\mathrm{H} 2)$ is rejected. Hence, it means transactional leadership style does not significantly affect organizational learning.

In a current research study, a model for organizational learning and laissez-faire leadership style indicates that the beta coefficient implies that a $1 \%$ change in the Laissez-faire leadership style will bring about a $12.0 \%$ change in organizational learning. In addition, the beta value is negative; therefore, it implies a negative relationship between organizational learning and Laissez-faire leadership style, i.e. an increase in the Laissez-faire leadership style is expected to bring a $12 \%$ decrease in organizational learning. Therefore, as the beta coefficient is significant, the null hypothesis is rejected, and it is 
concluded that there is a significant negative impact of the Laissez-faire leadership style of principals on organizational learning in the case of higher schools of Turkey.

\section{Mediation analysis}

Table 9. Model Summary for Mediation Analysis

\begin{tabular}{lll}
\hline Model & R & R Square \\
\hline 1 & .206 & .042 \\
2 & .271 & .073 \\
\hline
\end{tabular}

The value of $R$ square is 0.073 , which means $7.3 \%$ variation is explained in organizational learning due to leadership styles and organizational culture changes. Moreover, the value of $\mathrm{R}$ square depicts that $7.3 \%$ of data fits into the regression model.

Table 10. ANOVA

\begin{tabular}{llll}
\hline Model & & F & Sig. \\
\hline 1 & $\begin{array}{l}\text { Regression } \\
\text { Residual } \\
\text { Total }\end{array}$ & 4.525 & .004 \\
& $\begin{array}{l}\text { Regression } \\
\text { Residual } \\
\text { Total }\end{array}$ & 6.024 & .000 \\
\hline
\end{tabular}

The value of $\mathrm{F}$ for model 2 is more significant than six, and the significance value is 0.000 , which is less than 0.05 , so it means the model is significant with the existence of an independent and mediating variable.

Table 11. Coefficients for Hierarchical Regression

\begin{tabular}{llllll}
\hline \multirow{2}{*}{ Model } & & \multicolumn{3}{l}{ Unstandardized Coefficients } & \\
\cline { 3 - 5 } & & $\mathbf{B}$ & Std. Error & $\mathbf{t}$ & Sig. \\
\hline 1 & (Constant) & 2.634 & .269 & 9.777 & .000 \\
& TFL & .124 & .054 & 2.301 & .022 \\
& TSL & .138 & .073 & 1.883 & .061 \\
& LFL & -.105 & .050 & -2.117 & .035 \\
\hline 2 & (Constant) & 2.141 & .307 & 6.965 & .000 \\
& TFL & .105 & .054 & 1.964 & .050 \\
& TSL & .152 & .072 & 2.099 & .037 \\
& LFL & -.107 & .049 & -2.183 & .030 \\
& OC & .154 & .049 & 3.181 & .002 \\
\hline
\end{tabular}

The values of $t$ are far greater than 1 for all variables, and values of significance are less than 0.05 , so it means all null hypotheses related to mediating variables are rejected, and alternate hypotheses are accepted. As the value of significance is less than 0.05 for all variables, even in direct and indirect relationships, it means there is partial mediation of organizational culture on the relationship between independent and dependent variables.

Based on the Sobel Test, the value of Sobel Test Statistics is 0.25431 , and the value of one-tailed probability is 0.39962 , and the two-tailed probability is 0.79925 . Therefore, as the values of probability for mediation by the Sobel Test are between 0 and 1, it means there is a significant mediating effect of organizational culture on the relationship between leadership styles and organizational learning (AbuBader \& Jones, 2021).

In line with the hypotheses determined within the scope of the study, the analyses detailed above were carried out. As a result, the hypotheses H1, H3, H4, H5 and H6, determined within the study's scope and analysed simultaneously, were accepted.

\section{Discussions}

As per current findings, it is revealed that the TFL style of principal is perceived to be having the highest impact on organizational learning. Keawchaum (2017) claimed that when school principals follow a transformational leadership style, this ultimately builds an environment in which teachers are 
encouraged to play their best role in improving students' learning. Similar to this, Bouwmans et al. (2017) also argued that the transformational leadership style is one of the most effective leadership styles because it is directly linked with the improved performance of followers. When a teacher follows a transformational leadership style, this ultimately helps effective foster decision-making. In addition to this, the study has revealed no significant impact of transactional leadership style on organizational learning. This finding is the opposite of the findings of Zagoršek, Dimovski \& Škerlavaj (2009), who claimed that principals in schools follow a transactional leadership style. They give importance to giving rewards and perks to teachers. Giving rewards and perks to teachers proves to help enhance teachers' motivation level and encourage them to participate in students' learning activities fully. However, Berson, Nemanich, Waldman, Galvin, and Keller (2006) argued that the effect of the transactional leadership style is less than the transformational leadership style. In cases where the learning level in schools is not significantly improved, teachers' satisfaction and commitment levels are low with transactional leadership (Devece, Palacios \& Ribeiro-Navarrete, 2019).

Moreover, the punishments or rewards are proved dependent on the outcomes. The followers and leaders set some predefined objectives. Leaders who use transactional leadership provide specific tasks to followers and give punishments or rewards dependent on the outcomes. The followers and leaders set predefined objectives when they fail to fulfil the given objective, which ultimately does not enhance the organisation's learning level (Tang, 2019).

Along with this, another leadership style that has been studied in this research study is the laissez-faire leadership style. A laissez-faire leader does have direct followers' command and fails in giving good responses. This finding is similar to Kopia (2016) findings which stated that the laissez-faire leadership style is more familiar with trained and experienced workforce needing minor fall of supervision. However, the style of laissez-faire makes no leadership efforts from leaders that can result in increased costs, less control, and poor production. Besides this, the Laissez-faire leadership style hurts organizational learning. Similarly, Devece, Palacios, and Ribeiro-Navarrete (2019) also claimed that employees could abuse laissez-faire leadership, resulting in low accountability and such leadership style. It means following such a leadership style can result in low productivity by teachers, ultimately reducing the quality of organizational learning in schools.

Moreover, the study has revealed that it is always important to focus on the school's culture and give importance to leadership styles. The development of good organizational culture in schools improves the relationship between leadership styles and organizational learning. This finding is similar to the research study conducted by Curry et al. (2018), who stated that an organization helps enhance overall performance and learning ability within a firm. Therefore, it is always essential to develop culture so that people within a specific organization can feel motivated towards achieving both individual and organizational goals.

\section{Conclusions}

This study has been carried out for investigating the impact of leadership styles on organizational learning in high schools of Turkey. Moreover, the study also included an analysis of mediating role played by OC on the linkage between leadership style and OL. It has been found that there is a significant impact of leadership styles on organizational learning. Along with this, organizational culture significantly mediates the relationship between leadership styles and organizational learning. Transformational leadership provides a positive escalation in the leader's performance that surpasses the influences of some transactional leadership. It is identified as being significantly and positively linked with the satisfaction of followers. The transactional style of leadership is theorized to involve exemption management and contingent reward. In contingent reward, the leader's primary focus is over the classification of straightforward tasks that are done together with some rewards to be achieved on accomplishment that satisfies the exchange spirit between different parties.

On the other hand, management-by-exception implies leaders ensuring timely and proper accomplishment of some perspectives. Leaders who use transactional leadership provide some of the essential tasks for followers to perform. When principals in school follow a leissez-faire leadership style, the level of learning within schools gets reduced. Reduced level of learning is because following such a leadership style by principals reduces the cohesiveness of teams.

This research study proves to help add value to the literature because none of the prior research studies investigated the impact of leadership styles on organizational learning and the mediating effect of organizational culture. As the study is focused explicitly on higher educational institutions of Turkey, this provides essential information about how leadership styles of school principals can influence organizational learning, especially in the context of Turkish higher institutions. In addition to theoretical 
implications, the current research study also has practical implications. The findings of this study are beneficial for school principals of educational institutions, as they can get to know about the most effective leadership styles, which can prove to help enhance the level of learning within schools. Moreover, the management of schools can get to know about the importance of organizational culture for improving organizational learning within higher schools. Thus, the research study has both theoretical and practical implications. However, as the sample size is small, it cannot be generalized to larger sample size. So, in the future, researchers can focus on using a larger sample size. Moreover, future research studies can be conducted within other contexts, like in different countries.

\section{Peer-review:}

Externally peer-reviewed

\section{Conflict of interests:}

The author(s) has (have) no conflict of interest to declare.

\section{Grant Support:}

The author(s) declared that this study has received no financial support

\section{Ethics Committee Approval:}

Ethics committee approval was received for this study from Pamukkale University, and an application was made for the permission Ethics Committee on 27/01/2021 and E-93803232-622.02-13517 document number.

\section{References}

Arar, K., \& Nasra, M. A. (2019). Leadership style, occupational perception and organizational citizenship behavior in the Arab education system in Israel. Journal of Educational Administration, 57 (1), 85-100. Doi: https:// doi.org/10.1108/JEA-08-2017-0094

Abbas, G., Iqbal, J., Waheed, A., \& Naveed Riaz, M. (2012). Relationship between transformational leadership style and innovative work behavior in educational institutions. Journal of Behavioural Sciences, 22(3).

Abu-Bader, S., \& Jones, T. V. (2021). Statistical mediation analysis using the Sobel test and hayes SPSS process macro. International Journal of Quantitative and Qualitative Research Methods.

Andriani, S., Kesumawati, N., \& Kristiawan, M. (2018). The influence of the transformational leadership and work motivation on teachers performance. International Journal of Scientific \& Technology Research, $7(7), 19-29$.

Breevaart, K., \& Zacher, H. (2019). Main and interactive effects of weekly transformational and laissezfaire leadership on followers' trust in the leader and leader effectiveness. Journal of Occupational and Organizational Psychology, 92 (2), 384-409. Doi: https://doi.org/10.1111/joop.12253

Berson, Y., Nemanich, L. A., Waldman, D. A., Galvin, B. M., \& Keller, R. T. (2006). Leadership and organizational learning: A multiple levels perspective. The leadership quarterly, 17(6), 577-594. Doi: https://doi.org/10.1016/j.leaqua.2006.10.003

Bouwmans, M., Runhaar, P., Wesselink, R., \& Mulder, M. (2017). Fostering teachers' team learning: An interplay between transformational leadership and participative decision-making?, Teaching and Teacher Education, 65, 71-80. Doi: https://doi.org/10.1016/j.tate.2017.03.010

Curry, L. A., Brault, M. A., Linnander, E. L., McNatt, Z., Brewster, A. L., Cherlin, E., ... \& Bradley, E. H. (2018). Influencing organizational culture to improve hospital performance in care of patients with acute myocardial infarction: a mixed-methods intervention study. BMJ quality \& safety, 27(3), 207217. Doi: http://dx.doi.org/10.1136/bmjqs-2017-006989 
Devece, C., Palacios, D., \& Ribeiro-Navarrete, B. (2019). The effectiveness of crowdsourcing in knowledge-based industries: the moderating role of transformational leadership and organizational learning. Economic research-Ekonomska istraživanja, $32 \quad$ (1), 335-351. Doi: https://doi.org/10.1080/1331677X.2018.1547204

Daoud, J. I. (2017, December). Multicollinearity and regression analysis. In Journal of Physics: Conference Series (Vol. 949, No. 1, p. 012009). IOP Publishing.

Freund, R. J., Wilson, W. J., \& Sa, P. (2006). Regression analysis. Elsevier.

Erthal, A., \& Marques, L. (2018). National culture and organizational culture in lean organizations: a systematic review. Production Planning $\mathcal{E} \quad$ Control, 29(8), 668-687. Doi: https:/ / doi.org/10.1080/09537287.2018.1455233

Goddard, W., \& Melville, S. (2004). Research methodology: An introduction. Juta and Company Ltd.

Glambek, M., Skogstad, A., \& Einarsen, S. (2018). Workplace bullying, the development of job insecurity and the role of laissez-faire leadership: A two-wave moderated mediation study. Work $\mathcal{E}$ Stress, 32 (3), 297-312. Doi: https:// doi.org/10.1080/02678373.2018.1427815

Imran, M. K., Ilyas, M., \& Aslam, U. (2016). Organizational learning through transformational leadership. The learning organization. 23 (4), 232-248. Doi: https://doi.org/10.1108/TLO-09-20150053

Kalkan, Ü., Altınay Aksal, F., Altınay Gazi, Z., Atasoy, R., \& Dağlı, G. (2020). The relationship between school administrators' leadership styles, school culture, and organizational image. Sage Open, 10(1), 1-15. Do: https:/ / doi.org/10.1177/2158244020902081

Keawchaum, S. (2017). How transformational leadership influences organizational learning capability, psychologial contract and performance: a mixed methodology research in a Thai case study (Doctoral dissertation, University of Aberdeen).

Khan, N. A., \& Khan, A. N. (2019). What followers are saying about transformational leaders fostering employee innovation via organizational learning, knowledge sharing and social media use in public organizations?. Government Information Quarterly, 36(4), $101391 . \quad$ Doi: https:// doi.org/10.1016/j.giq.2019.07.003

Kopia, J. (2016). Study on integration and leadership styles of Management Systems based on a high level structure. In International Conference on Management, Leadership \& Governance (p. 431). Academic Conferences International Limited.

Kothari, C. R. (2004). Research methodology: Methods and techniques. New Age International.

Kumar, R. (2018). Research methodology: A step-by-step guide for beginners. Sage.

Limpert, E., \& Stahel, W. A. (2011). Problems with using the normal distribution-and ways to improve quality and efficiency of data analysis. PLoS One, 6(7), e21403.

Mannion, R., \& Davies, H. (2018). Understanding organizational culture for healthcare quality improvement. Bmj, 363. Doi: https://doi.org/10.1136/bmj.k4907

Muthiani, M. J. (2019). The Impact of Leadership on Learning Outcomes: A Study on Effective Leadership Style for Principals in Vocational Colleges, IGI Global, 308-327.

Mulford, B. (2005). Organizational Learning Questionnaire-Quality Evidence. Leading \& Managing, 11 (2), 46-54. Doi: 55bdd6e108aec0e5f44461af.pdf

Nguyen, T. T. N., \& Luu, T. M. N. (2019). Linking transformational leadership and organizational performance: An empirical investigation of manufacturing firms in Vietnam. Economics $\mathcal{E}$ Sociology, 12(2), 170.

Onorato, M. (2013). Transformational leadership style in the educational sector: An empirical study of corporate managers and educational leaders. Academy of Educational Leadership Journal, 17(1), 33.

O'Reilly III, C.A., Chatman, J. \& Caldwell, D.F. (1991). People and organizational culture: A profile comparison approach to assessing person-organization fit. Academy of management journal, 34 (3), 487-516. Doi: https://doi.org/10.5465/256404

Rijal, S. (2010). Leadership style and organizational culture in learning organization: A comparative study. International Journal of Management \& Information Systems (IJMIS), 14(5). 
Sadeghi, A., \& Pihie, Z. A. L. (2013). The role of transformational leadership style in enhancing lecturers' job satisfaction. International Journal of Business and Social Science, 4(8), 264-271.

Serinkan, C., Enli, P., Akcit, V. \& Kiziloglu, M. (2014). Evaluation Of Knowledge Level Of Cargo Companies About Their Organizational Learning and Team Management: An Empirical Research in Cargo Companies in Turkey. Procedia-Social and Behavioral Sciences, 116, pp.4170-4174. Doi: 10.1016/j.sbspro.2014.01.911

Serinkan, C., Kiziloglu, M., Akcit, V. \& Enli, P., 2014. Organizational learning capacity in cargo industry. Procedia-Social and Behavioral Sciences, 116, pp.4005-4009. Doi: https://doi.org/10.1016/j.sbspro.2014.01.881

Syakur, A., Susilo, T. A. B., Wike, W., \& Ahmadi, R. (2020). Sustainability of Communication, Organizational Culture, Cooperation, Trust and Leadership Style for Lecturer Commitments in Higher Education. Budapest International Research and Critics Institute (BIRCI-Journal): Humanities and Social Sciences, 3(2), 1325-1335. Doi: https:// doi.org/10.33258/birci.v3i2.980

Tang, K. N. (2019). Leadership styles and organizational effectiveness. In Leadership and Change Management, SpringerBriefs in Business. Springer, Singapore. https://doi.org/10.1007/978-981-13$\underline{8902-3 \_2}$

Tang, L. L., \& Yeh, Y. L. (2015). Effect of organizational culture, leadership style, and organizational learning on organizational innovation in the public sector. 品質學報, 22(5), 461-481.

Torlak, N. G., \& Kuzey, C. (2019). Leadership, job satisfaction and performance links in private education institutes of Pakistan. International Journal of Productivity and Performance Management. 68 (2), 276-295. Doi: https://doi.org/10.1108/IJPPM-05-2018-0182

Xie, L. (2019). Leadership and organizational learning culture: a systematic literature review. European journal of training and development.

Yang, I. (2015). Positive effects of laissez-faire leadership: conceptual exploration. Journal of Management Development. 34 (10), 1246-1261. Doi: https:// doi.org/10.1108/JMD-02-2015-0016

Zagoršek, H., Dimovski, V., \& Škerlavaj, M. (2009). Transactional and transformational leadership impacts on organizational learning. Journal for East European Management Studies, 14 (2), 144-165. 